Cite this article: Nasirov A.M., Gasimov E.K., Ibrahimova N.E., Rzayev F.H. Pathomorphological changes in the larvae cells of blood-sucking mosquitoes (Aedes caspius Pallas, 1771) affected by parasitizing microsporidium Amblyospora (=Thelohania) opacita Kudo, 1922. The Journal of V. N. Karazin Kharkiv National University, Series "Biology", 2020, 35, 101-109.

UDC: 576.895 .132 .2 .99

\title{
Pathomorphological changes in the larvae cells of blood-sucking mosquitoes (Aedes caspius Pallas, 1771) affected by parasitizing microsporidium Amblyospora (=Thelohania) opacita Kudo, 1922
}

A.M. Nasirov, E.K. Gasimov, N.E. Ibrahimova, F.H. Rzayev

Microsporidia are highly specialized obligate intracellular parasites. They affect various tissues of most animal groups. In Azerbaijan, 29 species and forms of microsporidia were recorded. Of these, 10 species (Amblyospora minuta, Pleistophora obesa, Thelohania opacita, Th. opacita caspius, Th. vexans, Stempellia captshagaica, St. magna, Nosema caspius, Nosema sp., Culicosporella sp.) were found in four species of blood-sucking mosquitos (Culix pipiens pipiens, Aedes vexans, A. caspius, Culex theileri). The collected larvae were identified using the key of Gutsevich et al. (1970). In the laboratory, the mosquito larvae were examined against a dark background under the microscope MBS-9 to distinguish individuals infected with microsporidia. Smears were stained with azure-eosin. Histological slices were prepared according to the Volkova and Yeletskiy method (1971); pathological changes in host tissues were identified using the electron microscope JEM 1400. In the course of our research conducted in 2017-2018 on the Absheron peninsula (Azerbaijan), the life stages of the microsporidium Amblyospora (=Thelohania) opacita Kudo, 1922 were found in the larvae of Aedes caspius Pallas, 1771. Examination of the infected host cell ultrastructure revealed the following changes: rough endoplasmic reticulum and mitochondria concentration around the parasite, an increase of cytoplasm volume, initiation of cell hypertrophy, disappearance of fat, protein granules and rough endoplasmic reticulum at later development stages, a decrease in the number of ribosomes in the cytoplasm and their simultaneous increase around the periphery of the nucleus, mitochondria degradation. These changes cause a delay in the larva development. Microsporidiosis affects the whole mosquito life cycle. The effect of microsporidia on the host organism manifests itself in the delayed larvae development and, in some cases, their early death. First of all, the lipid granules disappear supposedly because of the intensification of the host's aerobic metabolism to compensate for the energy loss caused by the developing parasites.

Key words: blood-sucking mosquitoes, larvae, microsporidia, changes in cells, ultrastructure.

\section{About the authors:}

A.M. Nasirov - Institute of Zoology, Azerbaijan National Academy of Sciences, A. Abbaszadeh Str., passage 128, block 504, Baku, Azerbaijan, AZ1004, nasirov.a50@mail.ru, https://orcid.org/0000-0001-6991-0334

E.K. Gasimov - Azerbaijan Medical University, S. Vurgun Str., 163, Baku, Azerbaijan, AZ1078, geldar1949@gmail.com, https://orcid.org/0000-0002-5104-4260

N.E. Ibrahimova - Institute of Zoology, Azerbaijan National Academy of Sciences, A. Abbaszadeh Str., passage 128, block 504, Baku, Azerbaijan, AZ1004, ibragimova.n.e@mail.ru, https://orcid.org/0000-0002-4531-3823

F.H. Rzayev - Institute of Zoology, Azerbaijan National Academy of Sciences, A. Abbaszadeh Str., passage 128, block 504, Baku, Azerbaijan, AZ1004; Azerbaijan Medical University, S. Vurgun Str., 163, Baku, Azerbaijan, AZ1078, fuad.zi@mail.ru, https://orcid.org/0000-0002-8128-1101

\section{Introduction}

Microsporidia (Phylum Microsporidia Balbiani, 1882) are highly specialized obligate intracellular parasites. They affect various tissues of most groups of vertebrate and invertebrate animals (Issi, 1986; Canning, Vavra, 2000). To date, more than 1400 species in 140 genera of microsporidia are described (Manafov et al., 2017). The greatest number of microsporidium species is found in insects, including bloodsucking mosquitoes of the Culicidae family. Mosquitoes are the hosts of more than 150 microsporidia species in 25 genera (Andreadis, 2007; Nasirov et al., 2018), and many papers concern their fauna (Khaliulin, 1973; Lavchenko, Issi, 1973; Kilochitskiy, Shermet, 1978; Khodzhaeva, 1988; Pankova et al., 2000; Simakova, 2013; Seyed-Mohammad et al., 2016). Microsporidia are considered to be agents of biological control for regulating the number of mosquito larvae (Alimov, 2007). The microsporidium Amblyospora (= Thelohania) opacita Kudo, 1922, parasitizing blood-sucking mosquitoes, is widely spread and has a wide range of hosts. For example, this species parasitizes in 12 mosquito species in Ukraine (Kilochitskiy, Shermet, 1978), eight species in Russia (Khaliulin, 1973), one species in Kazakhstan (Lavchenko, 1974), and three species in Uzbekistan (Khodzhaeva, Guliy, 1977). The geographic varieties 
of this species were recorded from other countries (White et al., 1994; Chapman et al., 1966; Kellen, 1966; Kellen et al., 1965). Microsporidia of this genus develop mainly in the host's fat body, although for some species, the development is also possible in hemocytes, ovaries, etc. (Khaliulin, Ivanov, 1971).

In Azerbaijan, 29 species and forms of microsporidia were registered. Of these, 10 species (Amblyospora minuta, Pleistophora obesa, Thelohania opacita, Th. opacita caspius, Th. vexans, Stempellia captshagaica, St. magna, Nosema caspius, Nosema sp., Culicosporella sp.) were found in four species of blood-sucking mosquitoes (Culix pipiens pipiens, Aedes vexans, A. caspius, Culex theileri) (Alikhanov, 1972, 1973a, 1973b, 1979, 1986; Alikhanov et al., 1985). In total, 24 species and 3 subspecies of mosquitoes are common in Azerbaijan (Namazov, 2016). Of these, three species are carriers of malaria (An. sacharovi, An. maculopennis, An. subalpinus).

To date, the Microsporidia research has moved to the new level with the use of electron microscopic methods. These methods contribute to the identification of structural diversity of the trophic stages and spores, the nature of their relationship with the host cell, and especially the pathological changes that occur in the host tissues and cells. Given the unique properties of these obligate intracellular parasites of blood-sucking mosquitoes and their high diversty, miscrosporidia may be considered as model objects of theoretical parasitology, cytology and molecular biology. In therms of practical application, microsporidia can by refarged as potential agents of biological control of malicious bloodsuckers, which was the basis for our research.

\section{Materials and methods}

The research was conducted in the Absheron region (Azerbaijan) from the end of May to the middle of September of 2017-2018. We collected mosquito larvae, identified them using Gutsevich et al., 1970, and then chose the specimens of Aedes caspius Pallas, 1971 for our study.

In the laboratory, the collected material was examined against a dark background under the microscope MBS-9 to distinguished individuals infected with microsporidia. Smears were fixed with methyl alcohol for 1-2 minutes, and then stained with azure-eosin according to Giemsa-Romanowsky (Voronin, Issi, 1974). For the histological slide preparation, we used the Volkova-Yeletskiy method (Volkova, Yeletskiy, 1971). The following steps were taken to identify pathological changes in host tissues with the use of electron microscope JEM 1400.

The obtained samples ( $3^{\text {rd }}$ and $4^{\text {th }}$ stage of infected mosquito larvae) were prepared in $0.1 \mathrm{M}$ phosphate buffer $(\mathrm{pH}=7.4)$, fixed in a solution of $2.5 \%$ glutaraldehyde, $2 \%$ paraformal-aldehyde, $4 \%$ sucrose, $0.1 \%$ picrinic acid and transferred to the Electron Microscopy Laboratory of the Scientific Research Centre of Azerbaijan Medical University. First, each sample was washed thrice in a $0.1 \mathrm{M}$ phosphate buffer ( $\mathrm{pH}=7.4$ ) for 15 minutes ( 45 minutes in total) in the laboratory. According to the common methods adopted in light and electron microscopic investigations, the slices were kept in the mixed solution of $1.5 \%$ red blood salt and $1 \% \mathrm{OsO}_{4}, 0.1 \mathrm{M}$ phosphate buffer for 1.5 hours in the post fixation phase. After that, each specimen was once again washed thrice in $0.1 \mathrm{M}$ phosphate buffer $(\mathrm{pH}=7.4)$ for 15 minutes and the slices were dehydrated at the III phase. In this case, each specimen was passed thrice through $50 \%$ alcohol, and then through $70 \%$ and $96 \%$ alcohol, consequently, for 15 minutes (45 minutes in total). Then each slice was washed thrice in the solution of $50 \%$ pure alcohol and $50 \%$ pure acetone for 15 minutes ( 45 minutes in total) and fixed thrice in pure acetone for 15 minutes ( 45 minutes in total). The next IV phase was the block preparation. For this purpose, the Araldite-Epon solution of five components (Epon-812, DDSA, Araldite M, Dibutalftalat and DMP-30) was used. The component proportions varied depending on the number of samples to be taken. The block preparation phase is divided into several parts: a) $75 \%$ of the solution is pure acetone and $25 \%$ is Araldite-Epon; b) $50 \%$ of the solution is pure acetone and $50 \%$ is Araldite-Epon; c) $25 \%$ of the solution is pure acetone and $75 \%$ is Araldite-Epon; d) the slices are kept in the solution of $100 \%$ Araldite-Epon for an hour (Kuo, 2007; Weakley, 1975).

After completing the last stage, the samples were placed in pre-selected and numbered readymolds and placed in a thermostat. The slices were kept a day at $37^{\circ} \mathrm{C}$, a day at $45^{\circ} \mathrm{C}$, and a day at $60^{\circ} \mathrm{C}$ (total 3 days) in thermostats. The ready-made blocks were removed from the molds and the semi-slim $(1 \mu)$ cuts were prepared via Leica EM UC7 thermal ultramicrotome. The sections were stained by double-dyeing method (a solution of $0.5 \%$ methylene abundance, $0.5 \%$ azur II, $0.5 \%$ buffer and bsolution $-5 \%$ alcohol, $0.1 \%$ fuchsine) (D'Amico, 2005). Semi-slim cuts were reviewed in the Promo Star (Zeiss) microscope and the images of the necessary parts were captured with the digital camera system Canon D650 (Japan). After the pyramids were developed from the selected areas of the necessary parts of semi-slim cuts observing by the light microscope, silver and gold ultraslim cuts were developed at 50 
$80 \mathrm{~nm}$ thick via the above mentioned ultramicrotomy and were collected into the grids. Further, the cuts were stained at $2 \%$ uranyl acetate solution for 15 minutes, then at $0.6 \%$ pure lead citrate prepared in $0.1 \mathrm{M} \mathrm{NaOH}$ solution for 0.5-1 minutes (Kuo, 2007) and examined using Transmission Electron Microscope. Ultraslim cuttings were investigated under the tension of 80-KV at JEM-1400 TEM (JOELJapan), and electronogrammes were taken with the lower and lateral cameras (Veleta).

\section{Results and discussion}

Our research in the Absheron Region in 2017-2018 revealed that the 3rd and 4th larvae stage of Aedes caspius are invaded with microsporidium Amblyospora (=Thelohania) opacita from May to late September. The light and electron microscopy techniques are widely used in the studies of pathological changes in the host tissues and cells in case of microsporidiosis (Chen, 1998; Becnel, Andreadis, 1998). We also used these methods in our research. First, microsporidium spores enter the intestinal cavity of blood-sucking mosquitoes. At this stage, no external symptoms are noticed. Parasites (spores) can be seen only on histological specimens and on electronogramms (Fig. 1, microsporidian spores are indicated by arrows). In the studies of microsporidia parasitizing blood-sucking mosquitoes (including the genus Amblyospora), N. Andreadis also confirms the above data on research methods, localization and symptoms (Andreadis, 2007). Sporoplasm is shot into the host cell with the help of a polar parasite tube. Sporoplasm is an invasive stage, represented by a single nucleus (or diplocaryon), surrounded by a thin layer of cytoplasm with monoribosomes. When in dispute, it does not have its own shell. Along the channel of the polar tube ejected from the spores, the parasite's core "squeezes" into the host cell. It can be said that the microsporidium gene is inserted into the host cell. In the host cell, the sporoplasm is already surrounded by its own plasma membrane. Few hours later, the sporoplasm increases in size, a rough endoplasmic reticulum (RER) appears in its cytoplasm, and it turns into meront, the proliferative stage of the microsporidium life cycle. We found several stages (meront, sporoblast and spore) of the parasite in the host cells in the larvae's fat bodies. A spore and its ultrastructure is shown in Fig. 2.

The host cell hypertrophy began with the onset of sporogony. At this stage, destructive changes occurred in the host cell: RER, fat and protein granules disappeared, the number of ribosomes decreased in the cytoplasm and at the same time increased along the periphery of the nucleus, mitochondria degraded. The hypertrophied cells are characterized by the nucleus hypertrophy with strong invagination of its shell and the formation of lobes that increase its surface, or even the appearance of multi-core. Liu (1972) found that the fat body cells infected by Thelohania bracteata can be distinguished from the uninfected ones by the presence of particles, which are larger in size and lower in density. Also, the nuclear pore has a larger diameter in the infected cells. In addition, the central granule in the nuclear pore complex is usually absent (Liu, 1972). The strongest pathological changes were peculiar to the cells of mesodermal origin. The infected cells that lost the ability to autolysis often live longer than those not infected. During insect metamorphosis, not being subjected to apoptosis, unlike the normal cells, they are transphasically transmitted from larvae to adult individuals.

The relationship of microsporidium with the mitochondria of the host cell (due to the fact that there are no mitochondria in microsporidium) is of particular interest (Dolgikh et al., 2011). It ranges from the complete absence of a visible reaction of these organelles to parasite invasion to the integration of the parasite cell with the mitochondria of the host cell. Electron diffraction patterns of many microsporidia show structured bonds between the membranes of the organelle and the parasite cell.

Microsporidiosis affects negatively the life cycle of mosquitoes. The effect of microsporidia on the host organism is manifested in the delayed larva development or sometimes its early death. At the initial stage, the lipid granules disappear, probably as a result of the intensification of the host's aerobic metabolism processes to compensate for the energy loss caused by the developing parasites. The above data are confirmed in blood-sucking mosquitoes of the genus Aedes infected by the microsporidium Thelohania opacita (Kilochitzky et al., 1980).

The influence of microsporidiosis on the mosquito larva hemolymph manifested itself in an increase in the prohemocyte proportion, in appearance of multicore free-circulating cells on the 6th day after infection, and in suppression of the hemolymph melanisation during mass parasite sporogenesis (Vorontsova et al., 2004). For some microsporidium species, the hemocyte participation in the spread of infection throughout the host organism has been shown (David, Weiser, 1994). There is also evidence of in vitro suppression of microsporidial spore phagocytosis (Ditrich et al., 1997) and the ability of microsporidia to multiply in insect hemocytes (Kozlov et al., 1988). A characteristic symptom of microsporidiosis of mosquito larvae is a deposition of black dots and small irregular-shaped spots under 
the cuticle ("atretization reaction"). At the same time, the larvae acquired a milky-white colour, which is the result of massive accumulation of spores in the fat body. Lipid granules are practically absent in the tissues with intensive infestation of parasites. In our research, a massive accumulation of spores (sporophore clusters) in the fat body was also visually observed on the 1st and 2nd abdominal segments of the larvae of blood-sucking mosquitoes infected with Amblyospora (=Thelohania) opacita microsporidia under a light microscope. On the histological specimens and on smears, the above-said was also clearly visible (Fig. 3, clusters are indicated with arrows).

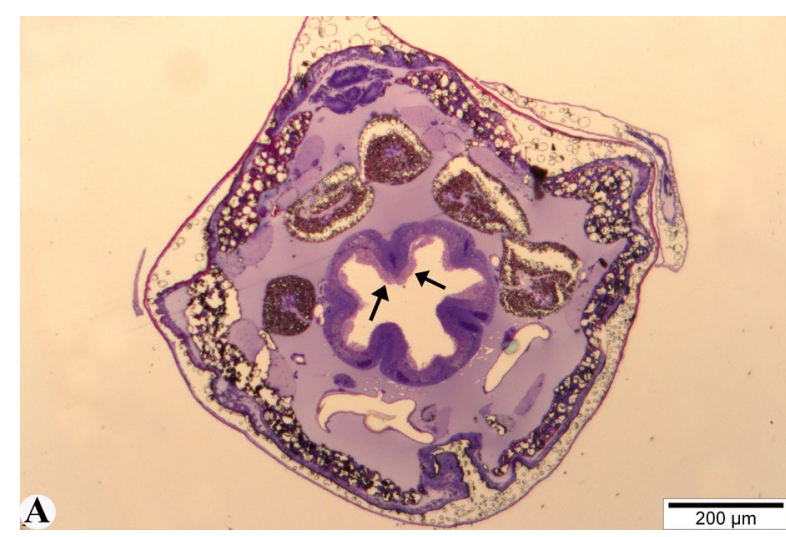

A

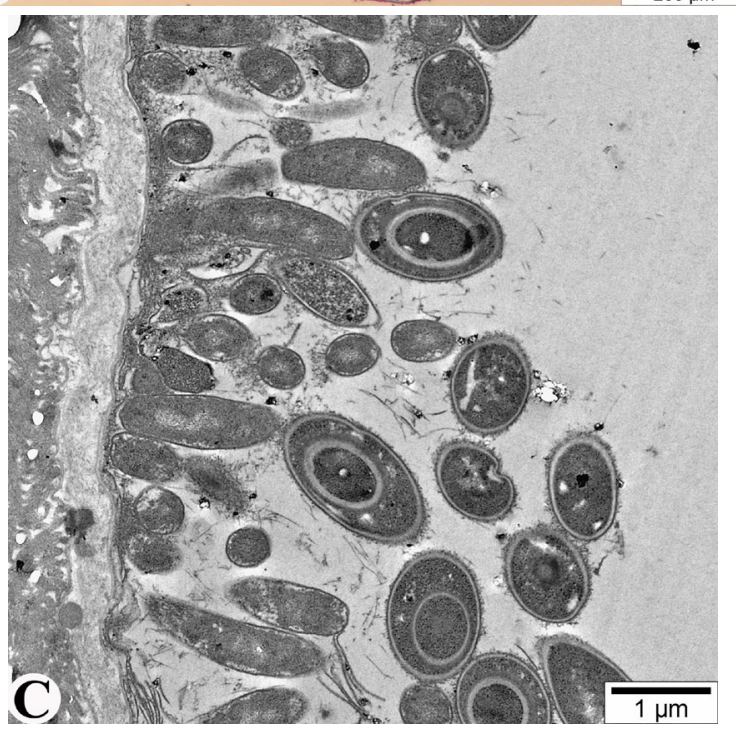

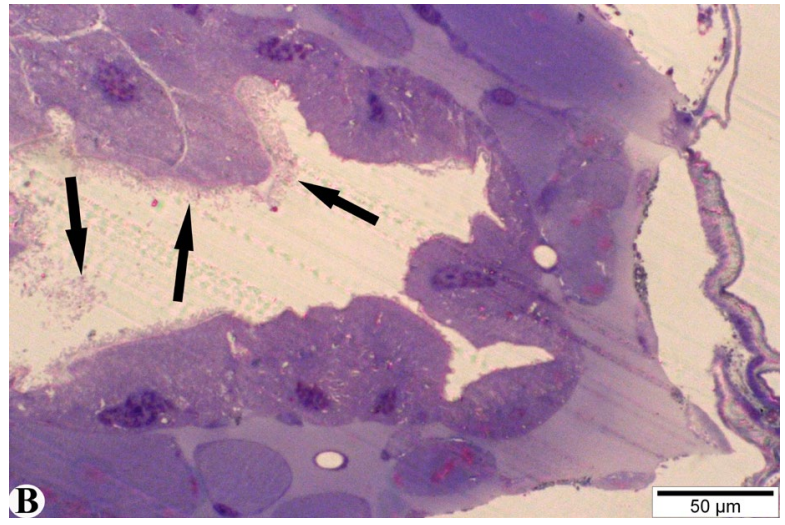

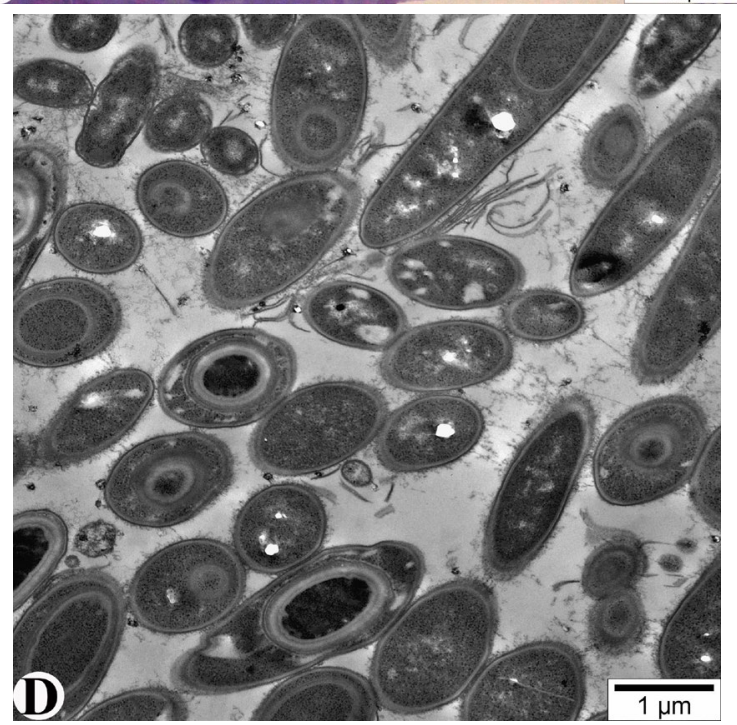

Fig. 1. Spores of the microsporidium Amblyospora (Thelohania) opacita in the larvae of the bloodsucking mosquito Aedes caspius. Explanations in the text. A and $B$ - light microscopy, semi-thin section (thickness $1 \mu \mathrm{m}$ ). D'Amico staining. $C$ and $D-$ electron microscopy, ultrathin sections (thickness $60 \mathrm{~nm}$ ). Staining: uranyl-acetate and lead citrate

According to other authors (Seleznyev, Raushenbakh, 2003), the cells infected with microsporidia are in a state of physiological stress. Neurosecretory brain cells stop prothoracotropic hormone secretion into hemolymph, and, as a result, the synthesis and secretion of the ecdysone, the moulting hormone, decreases, so, infected insects experience moulting difficulties. The juvenile hormone esterase activity decreases. For this reason, insects also have difficulties in undergoing metamorphosis. Infection with microsporidia leads to pathological disorders of hormone-dependent morphogenetic processes like cell differentiation and specialization, molting, metamorphosis, diapause, and insect reproduction (Alikhanov, 1973a; Issi, Tokarev, 2002). We are convinced that the mechanisms underlying parasite-host relations in microsporidiosis do not differ from the relationships in parasite-host systems formed by parasites of other systematic affiliation. 


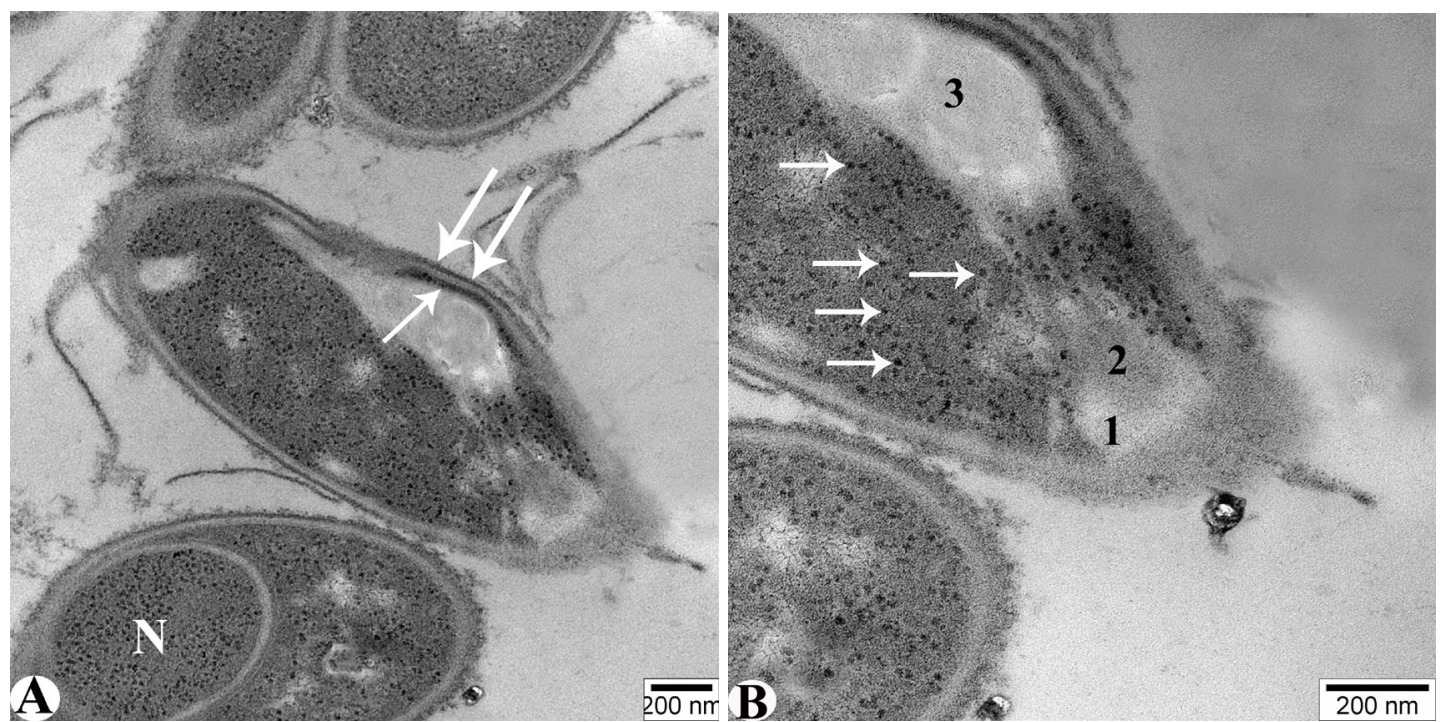

Fig. 2. Microsporidia Amblyospora (=Thelohania) opacita. A and B - electron microscopy, ultrathin sections (thickness $60 \mathrm{~nm}$ ). Staining: uranyl acetate and lead citrate. A: $\mathrm{N}$ - nucleus, one arrow endospore (chitin), two arrows - exospore (protein). B: arrows - ribosomes, 1 - anchoring disc, 2 polaroplast, 3 - polar tube
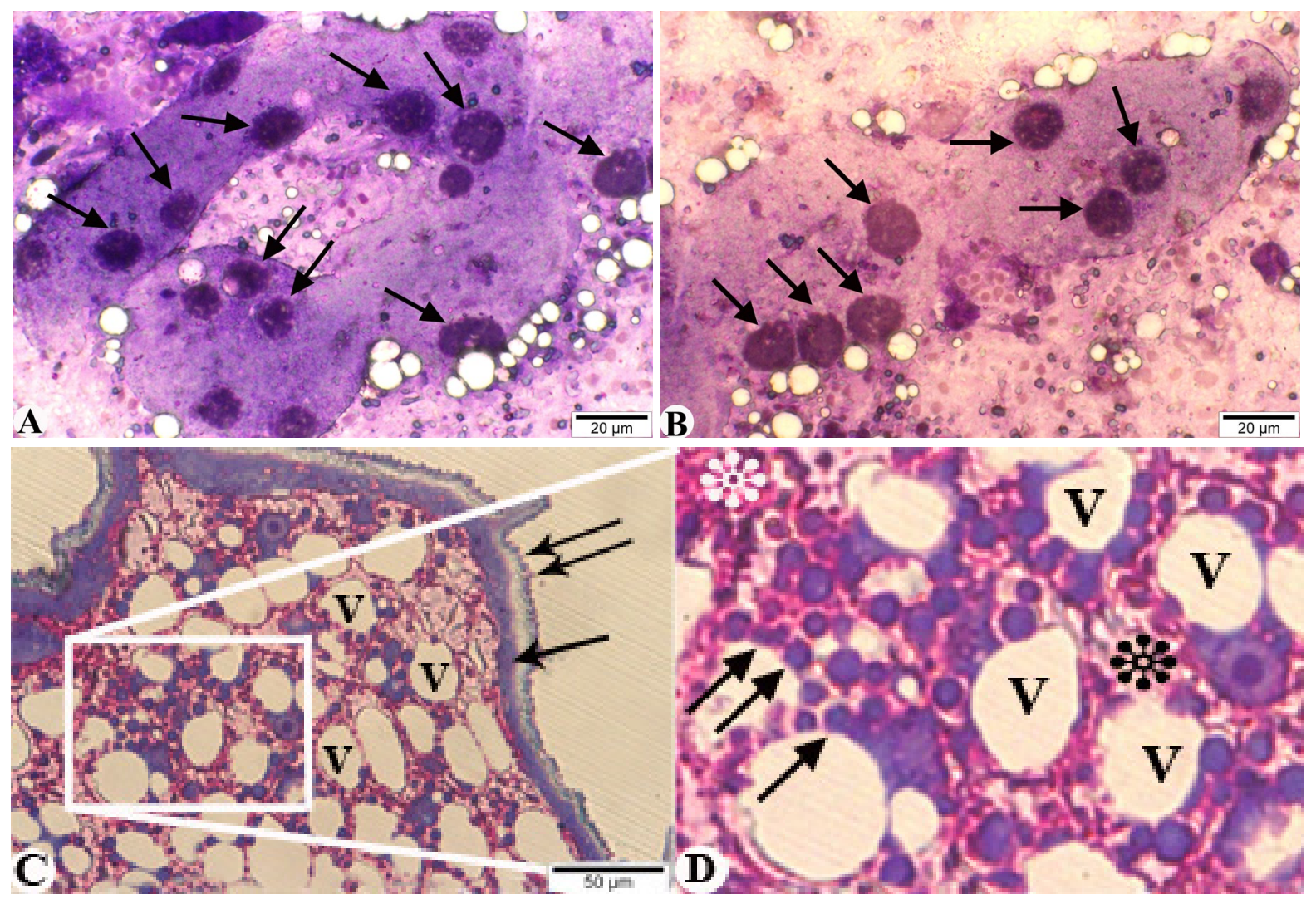

Fig. 3. Accumulation of microsporidium spores in the fat body of the mosquito larvae. Explanations in the text. A, B, C and D - light microscopy, semi-thin section (thickness 1 micron). D'Amico staining. C: $\mathrm{V}$ - vacuoles, one arrow - hypoderm of mosquito larvae, two arrows - cuticle. D: $\mathrm{V}$ - vacuoles, arrows sporophore clusters, flower - fat bodies 


\section{Conclusions}

1. The life cycle stages of the microsporidium Amblyospora (=Thelohania) opacita were revealed in the blood-sucking mosquito Aedes caspius in Absheron.

2. Ultrastructure studies of the infected mosquito cells showed that an increase in the cytoplasm volume of the host cells occurs at the initial stage of microsporidiosis. Rough endoplasmic reticulum and mitochondria of the host cell cytoplasm are concentrated around the parasite.

3. Host cell hypertrophy occurs at the initial stage of sporogony; RER, fat and protein granules in the cell cytoplasm disappear.

4. During sporogony, the destructive changes amplify, and the number of ribosomes in the host cell cytoplasm falls sharply. Mitochondria degradation and nucleus hypertrophy are observed.

\section{References}

Alikhanov Sh.G. (1972). On infection by microsporidia of the genus Thelohania of natural populations of the Aedes caspius caspius mosquito in Azerbaijan. Parazitologiia, 6(4), 381-384. (In Russian).

Alikhanov Sh.G. (1973a). The influence of microsporidia Thelohania opacita Kudo, 1922 on the growth and development of the larvae of the Aedes caspius caspius Pall. natural populations. Parazitologiia, 7(5), 389-391. (In Russian).

Alikhanov Sh.G. (1973b). Changes in the sex ratio of mosquitoes Aedes caspius caspius (Pall.) Edw. at infection of natural populations by microsporidia Thelohania opacita Kudo, 1922. Parazitologiia, 7(2), 175-179. (In Russian).

Alikhanov Sh.G. (1979). The effect of microsporidiosis on the fertility of mosquitoes Aedes caspius caspius (Culicidae). Parazitologiia, 3(14), 389-391. (In Russian).

Alikhanov Sh.G. (1986). Microsporidia daphnia and cyclops from artificial reservoirs of the Greater Caucasus within the Azerbaijan SSR. Parasites and aquatic invertebrate diseases. Moscow. P. 7-8. (In Russian).

Alikhanov Sh.G., Mikailov T.K., Ismailova S.T., Kurochenko G.N. (1985). Microsporidiosis of mosquitoes on the territory of the Kura-Araksi, Samur-Divichinskaya and Lenkoran lowlands of the Azerbaijan SSR. Dep. 05/17/1985, No. 3381-85. Dep. VINITI, 9. (In Russian).

Alimov A.F. (2007). Protista. Guide to Zoology. SPb. 1144 p. (In Russian).

Andreadis T.G. (2007). Microsporidian parasites of mosquitoes. J. Am. Mosq. Control. Assoc., 23(2 Suppl), 3-29. doi:10.2987/8756-971X(2007)23[3:MPOM]2.0.CO;2

Becnel J.J., Andreadis T.G. (1998). Amblyospora salinaria n. sp. (Microsporidia: Amblyosporidae), parasite of Culex salinarius (Diptera: Culicidae): its life cycle stages in an intermediate host. Journal of invertebrate pathology, 71(3), 258-262. https://doi.org/10.1006/jipa.1998.4729

Canning E., Vavra J. (2000). Phylum Microsporida. An illustrated guide to the Protozoa. Second edition. Kansas, USA, Society of Protozoologists. P. 39-126.

Chapman H.C., Woodard D.B., Kellen W.R., Clark T.B. (1966). Host parasitic relationships of Thelohania associated with mosquitoes in Louisiana. J. Invert. Pathol., 8(4), 452-456.

Chen W.J. (1998). A microsporidium of the predacious mosquito Culex fuscanus Wiedemann (Diptera: Culicidae) from Southern Taiwan. Journal of Invertebrate Pathology, 71(2), 179-181.

D'Amico F. (2005). A polychromatic staining method for epoxy embedded tissue: a new combination of methylene blue and basic fuchsine for light microscopy. Biotech. Histochem., 80(5-6), 207-210. https://doi.org/10.1080/10520290600560897

David A., Weiser J. (1994). Role of hemocytes in the propagation of a microsporidian infection in larvae of Galleria mellonella. J. Invertebr. Pathol., 63, 212-213. https://doi.org/10.1006/jipa.1994.1039

Ditrich O., Cross M.F., Jones J. et al. (1997). Strategies of microsporidial evasion of macrophage killing. Abstr. 2nd Workshop on Microsporidiosis and Cryptosporidiosis in Immunodeficient Patients. České Budějovice: Parazitologický ústav AV ČR, 19.

Dolgikh V.V., Senderskiy I.V., Pavlova O.A., Naumov A.M. (2011). Unique characteristics of the energy metabolism in microsporidia as a result of durational adaptation to the intracellular development. Parazitologiia, 45(2), 147-157. (In Russian).

Gutsevich A.V., Monchadsky A.S., Shtakelberg A.A. (1970). The fauna of the USSR. Insects Diptera, 3(4). 384 p. (In Russian).

Issi I.V. (1986). Microsporidia as a phylum of parasitic protozoa. Protozoology. Leningrad, Nauka, 10, 1136. (In Russian). 
Issi I.V., Tokarev Yu.S. (2002). Impact of the microsporidia on hormonal balance in insect hosts. Parazitologiia, 36(5), 405-421. (In Russian).

Kellen W.R. (1966). Transovarian transmission of some Thelohania in mosquitoes of California and Louisiana. J. Invert. Pathol., 8(3), 355-359. https://doi.org/10.1016/0022-2011(66)90050-4

Kellen W.R., Chapman H.C., Clark T.B., Lindegren J.E. (1965). Host - parasite relationships of some Thelohania from mosquitoes. J. Invert. Pathol., 7, 161-166.

Khaliulin G.L. (1973). Microsporidiosis of the larvae of blood-sucking mosquitoes of the middle Volga region. Parazitologiia, 7(4), 370-373. (In Russian).

Khaliulin G.L., Ivanov S.L. (1971). Infection of larvae of Aedes communis Deg. with the microsporidia Thelohania opacita Kudo in the Mari ASSR. Parazitologiia, 5(1), 98-100. (In Russian).

Khodzhaeva L.F. (1988). Microsporidia of blood-sucking dipterans. Ecology of animal parasites in the south-west of Uzbekistan. Tashkent. P. 81-87. (In Russian).

Khodzhaeva L.F., Guliy V.V. (1977). Microsporidia Thelohania opacita Kudo and metamorphosis in common mosquito species. Izv. SB AS USSR Ser. biol. sciences, 10(2), 109-112. (In Russian).

Kilochitskiy P.Y., Shermet V.P. (1978). Microsporidia of blood-sucking mosquitoes of the north of Ukraine. Bulletin of Zoology, 1, 62-66. (In Russian).

Kilochitzky P.Ja., Korzhov V.M., Sheremet V.P. (1980). The effect of microsporidians upon the calorific value of tissues of bloodsucking mosquitoes larvae. Parazitologiia, 14(4), 340-344. (In Russian).

Kozlov M.P., Nadeina V.P., Chumakova I.V. (1988). Hemolymph cells of fleas and their phagocytic activity. Parazitologiia, 22(4). 321-328. (In Russian).

Kuo J. (2007). Electron microscopy: methods and protocols. Totowa. $625 \mathrm{p}$.

Lavchenko N.G., Issi I.V. (1973). Microsporidia of blood-sucking dipterans. Regulators of the abundance of gnats in the south-east of Kazakhstan. Alma-Ata. P. 42-64. (In Russian).

Lavchenko N.G. (1974). The new host of the microsporidia Thelohania opacita Kudo, 1922. Proceedings of AN Kaz. SSR. Ser. biol., 4, 76-77. (In Russian).

Liu T.P. (1972). Ultrastructural changes in the nuclear envelope of larval fat body cells of Simulium vittatum (Diptera) induced by microsporidian infection of Thelohania bracteata. Tissue \& Cell, 4(3), 493502. https://doi.org/10.1016/S0040-8166(72)80025-9

Manafov A.A., Nasirov A.M., Bunyatova K.I. et al. (2017). Prospects of the study of microsporides of blood-sucking mosquitoes of Azerbaijan. Proceedings of the Institute of Zoology, 35(1), 76-82. (In Azeri).

Namazov N.C. (2016). Study of the current state of the species composition of mosquitos from the family Culicidae in Azerbaijan and develop control measures against them. Dr. Thesis. Baku. $41 \mathrm{p}$.

Nasirov A.M., Bunyatova K.I., Ibrahimova N.E., Rzayev F.H. (2018). The significance of the microsporidium Thelohania opacita in the spread of blood-sucking mosquitoes on the territory of Absheron. VI Congress of the Parasitological Society: Modern parasitology - main trends and challenges. St. Petersburg. P. 168. (In Russian).

Pankova T.F., Issi I.V., Simakova A.V. (2000). New species of microsporidians Amblyospora from bloodsucking mosquitos of the family Culicidae. Parazitologiia, 34(5), 420-430. (In Russian).

Seleznev K.V., Raushenbakh I.Yu. (2003). Parasitic stress hypothesis in insect infection with microsporidia. Parazitologiia, 37(4), 316-232. (In Russian).

Seyed-Mohammad O., Seyedeh-Fatemeh M., Kourosh M. (2016). Microsporidium infecting Anopheles Supepictus (Diptera: Culicidae) larvae. J. Arthropod-Borne Dis., 10(3), 413-420.

Simakova A.V. (2013). Microsporidia (Microsporidia) of blood-sucking mosquitoes (Diptera: Culicidae) of Western Siberia (species composition, ecology, molecular phylogeny). Thesis of Doc. Biol. Sciences. Tomsk. 370 p. (In Russian).

Volkova O.V., Yeletskiy Yu.K. (1971). Fundamentals of histology and histological techniques. Moscow: Meditsina. 272 p. (In Russian).

Voronin V.I., Issi I.V. (1974). About the methods of working with microsporidia. Parazitologiia, 8(3), 272 273. (In Russian).

Vorontsova Ya.L., Tokarev Yu.S., Sokolova Yu.Ya., Glupov V.V. (2004). Galleria mellonella bee moth microsporidiosis (Lepidoptera: Pyralidae), caused by Vairimorpha ephestiae (Microsporidia: Burenellidae). Parazitologiia, 38(3), 239-150. (In Russian).

Weakley B. (1975). Electron microscopy for beginners. Moscow: Mir. 325 p. (In Russian). 
White S.E., Fukuda T., Undeen A.H. (1994). Horizontal transmission of Amblyospora opacita (Microspora: Amblyosporidae) between the Mosquito, Culex territans, and the copepod, Paracyclops fimbriatus chiltoni. Journal of Invertebrate Pathology, 63(1), 19-25. https://doi.org/10.1006/jipa.1994.1004

\title{
Патоморфологічні зміни у клітинах личинок кровосисних комарів (Aedes caspius Pallas, 1771) при паразитуванні мікроспоридії Amblyospora \\ (=Thelohania) opacita Kudo, 1922 \\ А.М. Насиров, Е.К. Касимов, Н.Е. Ібрагімова, Ф.Г. Рзаєв
}

\begin{abstract}
Мікроспоридії є групою високоспеціалізованих облігатних внутрішньоклітинних паразитів. Вони вражають різні тканини більшості груп тварин. В Азербайджані було виявлено 29 видів і форм мікроспоридій. 3 них 10 видів (Amblyospora minuta, Pleistophora obesa, Thelohania opacita, Th. opacita caspius, Th. vexans, Stempellia captshagaica, St. magna, Nosema caspius, Nosema sp., Culicosporella sp.) були відзначені у 4-х видів (Сulix pipiens pipiens, Aedes vexans, A. caspius, Culex theileri) кровосисних комарів. Видову приналежність зібраних личинок встановлювали за визначником А.В. Гуцевич та ін. (1970). Зібрані екземпляри комах переглядали на темному тлі мікроскопа МБС-9 для виявлення особин, заражених мікроспоридіями. Мазки фарбували азуреозином. Для приготування гістологічних препаратів використовували метод О.В. Волкової і Ю.К. Єлецького (1971), а для виявлення патоморфологічних змін в личинках використовували електронний мікроскоп (JEM1400). Дослідження наявності мікроспоридій у кровосисних комарів виду Aedes caspius Pallas, 1771, проведені нами в 2017-2018 рр. на території Абшерона (Азербайджан), виявили стадії життєвого циклу мікроспоридій Amblyospora (=Thelohania) opacita Kudo, 1922. Вивчено ультраструктуру інвазивних клітин господаря і встановлено, що шорстка ендоплазматична сітка і мітохондрії клітини господаря концентруються навколо паразита, обсяг цитоплазми збільшується, починається гіпертрофія клітин, в подальшому зникають шорстка ендоплазматична сітка, жирові і білкові гранули, кількість рибосом зменшується в цитоплазмі і одночасно збільшується по периферії ядра, деградують мітохондрії, відбувається затримка розвитку личинок. Мікроспоридіоз негативно діє на цикл розвитку кровосисних комарів. Вплив мікроспоридій на організм господаря виявляється у затримці розвитку личинок або, іноді, їх ранньої загибелі. В першу чергу відбувається зникнення ліпідних гранул, ймовірно, як результат інтенсифікації процесів аеробного метаболізму господаря для відшкодування енергетичного збитку, нанесеного паразитами, які розвиваються.
\end{abstract}

Ключові слова: кровосисні комарі, личинки, мікроспоридії, зміни в клітинах, ультраструктура.

Про авторів:

А.М. Насиров - Інститут зоології НАН Азербайджану, вул. А. Аббасзаде, проїзд 1128, квартал 504, Баку, Азербайджан, AZ1004, nasirov.a50@mail.ru, https://orcid.org/0000-0001-6991-0334

Е.К. Касимов - Азербайджанський медичний університет, вул. С. Вургуна, 163, Баку, Азербайджан, AZ1078, geldar1949@gmail.com, https://orcid.org/0000-0002-5104-4260

Н.Е. Ібрагімова - Інститут зоології НАН Азербайджану, вул. А. Аббасзаде, проїзд 1128, квартал 504, Баку, Азербайджан, AZ1004, ibragimova.n.e@mail.ru, https://orcid.org/0000-0002-4531-3823

Ф.Г. Рзаєв - Інститут зоології НАН Азербайджану, вул. А. Аббасзаде, проїзд 1128, квартал 504, Баку, Азербайджан, AZ1004; Азербайджанський медичний університет, вул. С. Вургуна, 163, Баку, Азербайджан, AZ1078, fuad.zi@mail.ru, https://orcid.org/0000-0002-8128-1101

\section{Патоморфологические изменения в клетках личинок кровососущих комаров (Aedes caspius Pallas, 1771) при паразитировании микроспоридии Amblyospora (=Thelohania) opacita Kudo, 1922 \\ А.М. Насиров, Э.К. Касымов, Н.Э. Ибрагимова, Ф.Г. Рзаев}

Микроспоридии представляют собой группу высокоспециализированных облигатных внутриклеточных паразитов. Они поражают различные ткани большинства групп животных. В Азербайджане было выявлено 29 видов и форм микроспоридий. Из них 10 видов (Amblyospora minuta, Pleistophora obesa, Thelohania opacita, Th. opacita caspius, Th. vexans, Stempellia captshagaica, St. magna, Nosema caspius, Nosema sp., Culicosporella sp.) были отмечены у 4-х видов (Culix pipiens pipiens, Aedes vexans, A. caspius, Culex theileri) кровососущих комаров. Видовую принадлежность собранных личинок устанавливали по определителю А.В. Гуцевич и др. (1970). Собранные экземпляры насекомых просматривали на темном фроне микроскопа МБС-9 для выявления особей, зараженных микроспоридиями. Мазки красили азур-эозином. Для приготовления гистологических препаратов использовался метод О.В. Волковой и Ю.К. Елецкого (1971), а для выявления патоморфологических изменений в личинках использовали электронный микроскоп (JEM-1400). Исследования наличия микроспоридий у кровососущих комаров вида Aedes caspius Pallas, 1771, 
проведенные нами в 2017-2018 гг. на территории Абшерона (Азербайджан), выявили стадии жизненного цикла микроспоридий Amblyospora (=Thelohania) opacita Kudo, 1922. Изучена ультраструктура инвазивных клеток хозяина и установлено, что шероховатая эндоплазматическая сеть и митохондрии клетки хозяина концентрируются вокруг паразита, объем цитоплазмы увеличивается, начинается гипертрофия клеток, в дальнейшем исчезают шероховатая эндоплазматическая сеть, жировые и протеиновые гранулы, число рибосом уменьшается в цитоплазме и одновременно увеличивается по периферии ядра, деградируют митохондрии, происходит задержка развития личинок. Микроспоридиоз негативно действует на цикл развития кровососущих комаров. Влияние микроспоридий на организм хозяина проявляется в задержке развития личинок или, иногда, их ранней гибелью. В первую очередь происходит исчезновение липидных гранул, вероятно, как результат интенсификации процессов аэробного метаболизма хозяина для возмещения энергетического ущерба, нанесенного развивающимися паразитами.

Ключевые слова: кровососущие комары, личинки, микроспоридии, изменения в клетках, ультраструктура.

\section{O6 авторах:}

А.М. Насиров - Институт зоологии НАН Азербайджана, ул. А. Аббасзаде, проезд 1128, квартал 504, Баку, Азербайджан, AZ1004, nasirov.a50@mail.ru, https://orcid.org/0000-0001-6991-0334

Э.К. Касымов - Азербайджанский медицинский университет, ул. С. Вургуна, 163, Баку, Азербайджан, AZ1078, geldar1949@gmail.com, https://orcid.org/0000-0002-5104-4260

Н.Э. Ибрагимова - Институт зоологии НАН Азербайджана, ул. А. Аббасзаде, проезд 1128, квартал 504, Баку, Азербайджан, AZ1004, ibragimova.n.e@mail.ru, https://orcid.org/0000-0002-4531-3823

Ф.Г. Рзаев - Институт зоологии НАН Азербайджана, ул. А. Аббасзаде, проезд 1128, квартал 504, Баку, Азербайджан, AZ1004; Азербайджанский медицинский университет, ул. С. Вургуна, 163, Баку, Азербайджан, AZ1078, fuad.zi@mail.ru, https://orcid.org/0000-0002-8128-1101

Подано до редакції / Received: 14.10.2019 